\title{
THE ASSOCIATION BETWEEN ANXIETY AND COPING STRATEGY IN GENERAL INDONESIAN POPULATION DURING COVID-19 PANDEMIC
}

\author{
Indri Yunita Suryaputri, Tri Wuri Sastuti, Rofingatul Mubasyiroh
}

National Institute of Health Research and Development, Ministry of Health, Republic of Indonesia

\begin{abstract}
Background: Anxiety is a feeling of fear, worry, or unease. It can be reaction to stress, or it can occur in people who are unable to identify significant stressors in their life. Coping strategies are a set of cognitive and behavioral efforts made to interpret and correct a stressful situation and reduce its resulting suffering. The study aimed to assess the association between anxiety and coping strategies in Indonesian people during COVID-19 pandemic.

Subjects and Method: This was a cross-sectional study conducted online with population across Indonesia in May 2020. A sample of 2,189 people aged 15 years old or above who had smart phones was selected for this study. The dependent variable was anxiety. The independent variables were spiritual activity, exercise, recreation, and smoking/ alcohol drinking. Anxiety was measured by Generalized Anxiety Disorder (GAD-7). The data were analyzed by a multiple logistic regression.

Results: The risk of anxiety decreased with spiritual activity $(\mathrm{OR}=0.34 ; 95 \% \mathrm{CI}=0.12$ to $0.95 ; \mathrm{p}=0.045)$, doing exercise $(\mathrm{OR}=0.27 ; 95 \% \mathrm{CI}=0.15$ to $0.48 ; \mathrm{p}<0.001)$, and recreation $(\mathrm{OR}=0.26 ; 95 \% \mathrm{CI}=0.15$ to $0.48 ; \mathrm{p}<0.001)$. The risk of anxiety increased with smoking/ alcohol drinking $(\mathrm{OR}=2.17 ; 95 \% \mathrm{CI}=1.04$ to $4.52 ; \mathrm{p}=0.039)$.

Conclusion: The risk of anxiety decreases with spiritual activity, doing exercise, and recreation during COVID-19 pandemic, but increases with smoking/ alcohol drinking.
\end{abstract}

Keywords: anxiety, coping strategy, exercise, COVID-19 pandemic

\section{Correspondence:}

Indri Yunita Suryaputri. National Institute of Health Research and Development, Ministry of Health, Republic of Indonesia. Jl. Percetakan Negara 29, Jakarta, Indonesia. Email: indri.ysp@gmail.com. Mobile: +62 81316865446. 